\title{
GAMBARAN PENGETAHUAN IBU TENTANG STUNTING DI DESA LEBIH KABUPATEN GIANYAR TAHUN 2020
}

\author{
Ni Made Indra Peratiwi ${ }^{1,2}$, Cokorda Istri Mita Pemayun ${ }^{1,2}$, Ni Desak Made Intan Guna Yanti ${ }^{1,2}$ \\ ${ }^{1}$ Program Studi Diploma III Kebidanan, ${ }^{2}$ STIKES Advaita Medika Tabanan \\ Korespodensi penulis: indra.peratiwi2013@gmail.com
}

\begin{abstract}
Abstrak
Latar belakang: Stunting merupakan masalah gizi kronis yang dialami oleh Negara Indonesia yang harus ditangani. Stunting adalah kondisi gagal tumbuh pada anak balita yang diakibatkan kekurangan gizi kronis sehingga anak terlalu pendek untuk usianya. Pentingnya dilakukan penelitian tentang stunting agar dapat membantu pemerintah dalam menjalankan program kerja untuk menurunkan angka kejadin stunting.

Tujuan: Tujuan penelitian ini yaitu mengetahui gambaran pengetahuan ibu tentang stunting di Desa Lebih Kabupaten Gianyar tahun 2020.

Metode: Metode pelaksanaan penelitian ini yaitu deskriptif dengan rancangan crosssekctional. Sampel dalam penelitian ini yaitu ibu balita yang berjumlah 78 orang dan diambil secara sempling sistematis. Penelitian ini dilakukan di Desa Lebih Kabupaten Gianyar pada bulan Agustus 2020. Pengolaham data menggunakan analisis univariat.

Hasil: penelitian menunjukkan bahwa sebagian besar responden memiliki pengetahuan baik tentang stunting yaitu sebanyak 65 orang $(83,3 \%)$.

Simpulan: Jadi kesimpulan dalam penelitian ini adalah gambaran pengetahuan ibu tentang stunting di Desa Lebih Kabupaten Gianyar sebagian besar dalam kategori baik.
\end{abstract}

Kata kunci: Balita, Pengetahuan Ibu, Stunting

\section{Pendahuluan}

Stunting perupakan masalah gizi kronis dan menjadi salah satu masalah terpenting yang harus ditangani pemerintah di dunia maupun di Indonesia untuk memperoleh generasi yang baik.Salah satu indikator kesehatan yang dinilai keberhasilan pencapaiannya dalam MDGs adalah staus gizi Balita.Status gizi balita diukur berdasarkan umur (U), berat badan (BB) dan tinggi badan (TB).Variabel BB dan TB ini disajikan dalam bentuk tiga indikator antropometri, yaitu berat badan menurut umur $(\mathrm{BB} / \mathrm{U})$, tinggi badan menurut umur $(\mathrm{TB} / \mathrm{U})$, dan berat badan menurut tinggi badan $(\mathrm{BB} / \mathrm{TB})$.Indikator $\mathrm{BB} / \mathrm{U}$ memberikan indikasi masalah gizi secara umum.Indikator ini tidak memberikan indikasi tentang masalah gizi yang sifatnya kronis ataupun akut karena berat badan berkolerasi positif dengan umur dan tinggi badan.Dengan kata lain, berat badan yang rendah dapat disebabkan karena anaknya pendek (kronis) atau karena diare atau penyakit infeksi lain (akut) (WHO, 2017).

Kejadian balita pendek atau stunting merupakan salah satu masalah gizi yang dialami oleh balita di dunia saat ini. Pada tahun 2017 sebanyak 22,2\% atau sekitar 150,8 juta balita di dunia mengalami stunting.Jika dipersentasekan, $55 \%$ berasal dari Asia dan 39\% dari Afrika. Proporsi balita stunting di Asia yang terbanyak berasal dari Asia Selatan yaitu sebanyak $(58,7 \%)$ (WHO, 2017).Data prevalensi balita stunting yang dikumpulkan World Health Organization (WHO), Indonesia termasuk ke dalam negara ketiga dengan prevalensi tertinggi di regional Asia Tenggara/SouthEast Asia Regional (SEAR). Rata-rata 
prevalensi balita stunting di Indonesia tahun 2005-2017 adalah 36,4\%. Kejadian balita stunting (pendek) merupakan masalah gizi utama yang dihadapi Indonesia.Berdasarkan data Pemantauan Status Gizi (PSG) selama tiga tahun terakhir, balita pendek memiliki prevalensi tertinggi dibandingkan dengan masalah gizi lainnya seperti gizi kurang, kurus, dan gemuk. Prevalensi balita pendek mengalami peningkatan dari tahun 2016 yaitu $27,5 \%$ menjadi $29,6 \%$ pada tahun 2017 . Masalah balita pendek di Indonesia merupakan masalah kesehatan masyarakat yang masuk dalam kategori masalah kronis (WHO, 2017).

Hasil PSG di Provinsi Bali terdapat tiga kabupaten yang memiliki angka kejadian stunting.Kabupaten yang terbanyak memiliki angka kejadian stunting yaitu di Kabupaten Gianyar kemudian Kelungkung dan Singaraja. Pada tahun 2015, 2016 dan 2017 untuk indikator $\mathrm{BB} / \mathrm{U}, \mathrm{TB} / \mathrm{U}$ dan $\mathrm{BB} / \mathrm{T}$ tercatat prevalensi balita pendek cenderung tinggi, dimana terdapat $8,5 \%$ balita sangat pendek dan 19,0\% balita pendek. Di Kabupaten Gianyar status gizi balita tahun 2018 dengan indikator balita gizi kurang $\mathrm{BB} / \mathrm{U} 28$ orang $(8.3 \%$ ) balita pendek TB/U 69 ( $20.5 \%$ ) balita kurus BB/TB 18 orang ( $5.3 \%$ ) dari hasil penimbangan yang dilakukan di posyandu. Ada 10 (sepuluh) desa di Kabupaten Gianyar yang memiliki angka stunting yang cukup tinggi. Desa-desa tersebut adalah Desa Lebih, Sigaran, Lodtuduh, Singakerta, Sanding, Manukaya, Pupuan, Taro, Kedisan dan Bresela (Dinkes, 2019).

Penyebab masalah gizi dipengaruhi oleh dua faktor yaitu faktor langsung dan tidak langsung.Penyebab langsung yaitu faktor makanan dan penyakit infeksi.Faktor penyebab tidak langsung meliputi ketahanan pangan dalam keluarga, pola asuh, perawatan kesehatan dan sanitasi lingkungan yang kurang memadai.Keempat faktor tidak langsung tersebut saling berkaitan dengan pendidikan, pengetahuan, penghasilan, dan keterampilan ibu (Sasmito, 2007).

Penyebab munculnya kekurangan gizi paling kompleks adalah faktor pengetahuan dan perilaku pemberian makanan atau pola asuh gizi yang salah.Banyak faktor yang menyebabkan tingginya kejadian stunting pada balita.Penyebab langsung adalah kurangnya asupan makanan dan adanya penyakit infeksi (Umeta, 2013).

Pengetahuan seorang ibu akan mempengaruhi status pertumbuhan dan perkembangan anak dan sangat diperlukan untuk mendukung dalam proses pertumbuhan dan perkembangannya. Pengetahuan ibu yang kurang, pola asuh yang salah, sanitasi dan hygiene yang buruk dan rendahnya pelayanan kesehatan. Selain itu masyarakat belum menyadari anak pendek merupakan suatu masalah, karena anak pendek di masyarakat terlihat sebagai anak-anak dengan aktivitas yang normal, tidak seperti anak kurus yang harus segera ditanggulangi (Unicef, 2016).

Berdasarkan survei awal di Puskesmas Gianyar I di Desa Lebih Kabupaten Gianyar diperoleh data bahwa di Desa Lebih memiliki tiga banjar yaitu Kesian, Lebih Kaja dan Lebih Kelod. Di Banjar Kesian terdapat 150 balita dan 13 balita stunting.Di Banjar Lebih Kaja terdapat 89 balita dan 17 balita stunting.Di Banjar Lebih Kelod terdapat 133 balita dan 15 balita stunting.Dari keseluruhan terdapat 372 balita dan data dari pencatataan status gizi balita Puskesmas Gianyar I terdapat 45 balita mengalami stunting.

Sebagai perbandingan di Puskesmas Rejosari Kecamatan Tenayan Raya, diperoleh data bahwa terdapat 1361 balita. Data dari pencatatan status gizi balita Puskesmas Tenayan Raya, terdapat 44 orang balita dengan kategori sangat pendek dan 161 orang balita dengan kategori pendek. Dari hasil wawancara dengan 10 orang ibu balita, sebanyak 6 orang di antaranya menyatakan kurang mengetahui tentang stunting.Sedangkan, hasil wawancara dengan 4 orang ibu balita menyatakan bahwa mereka belum mengetahui penyebab stunting. Selain itu, dari hasil wawancara dengan 2 orang ibu balita, mereka mengetahui tentang stunting, tetapi ibu balita hanya mengetahui istilah stunting saja dan tidak mengetahui penyebab maupun penanggulangannya. 
Berdasarkan uraian latar belakang di atas,maka peneliti tertarik mengambil penelitian yang berjudul Gambaran Pengetahuan Ibu Tentang Stunting di Desa Lebih Kabupaten Gianyar karena di desa tersebut angka kejadian stunting masih sangat tinggi.

\section{Metode Penelitian}

Penelitian ini menggunakan adalah metode desktiptif dengan pendekatan crosssectional.Dimana penelitian melakukan pengukuran atau observasi data variabel hanya satu kali pada satu saat (Nursalam, 2016).Penelitian ini dilaksanakan di Desa Lebih Kabupaten Gianyar. Penelitian ini dilakukan pada bulan Agustus 2020.Populasi dalam penelitian ini adalah ibu yang memiliki balita dari usia 0-5 tahunyang ada di Desa Lebih berjumlah 78 orang. Teknik sampling yang digunakan dalam penelitian ini adalah sampling sistematis yaitu suatu teknik penetapan sampel dengan cara memilih sampeberdasarkan urutan dari anggota populasi yang terdiri dari 372 .

Pengambilan sampel yang akan digunakan yaitu mengambil kelipatan lima. Sehingga sampel tersebut dapat mewakili karakteristik populasi yang telah dikenal sebelumnya (Nursalam, 2017).Dalam penelitian ini analisis univariat yang dilakukan adalah mendistribusikan karakteristik responden yaitu umur, pendidikan dan pekerjaan serta mendistribusikan gambaran pengetahuan.

3. Hasil dan Pembahasan

Tabel 1 DistribusiFrekuensi Karakteristik Responden

\begin{tabular}{lll}
\hline Karakteristik responden & Frekuensi (f) & Persentase (\%) \\
\hline Umur & 1 & \\
$<20$ & 59 & 1.3 \\
$20-30$ & 18 & 75.6 \\
$>30$ & 78 & 23.1 \\
Total & 2 & $100 \%$ \\
\hline Pendidikan & \\
SD & 12 & 2.6 \\
SMP & 47 & 15.4 \\
SMA & 17 & 60.3 \\
Perguruan tinggi & 78 & 21.8 \\
Total & & $100 \%$ \\
\hline Pekerjaan suami responden & 48 & \\
Swasta & 16 & 61.5 \\
Wiraswasta & 3 & 20.5 \\
Nelayan & 11 & 3.8 \\
Pedagang & 78 & 14.1 \\
Total & & $100 \%$ \\
Pekerjaan responden & 12 & \\
Tidak bekerja & 1 & 15.4 \\
PNS & 36 & 1.3 \\
Swasta & 9 & 46.2 \\
Wirausaha & 20 & 11.5 \\
Pedagang & 78 & 25.6 \\
Total & & $100 \%$ \\
\hline Pennghasilan keluarga responden & & \\
$<5.000 .000$ & 17 & 21.8 \\
5.000.000-8.000.000 & 60 & 76.9 \\
$>8.000 .000$ & 1 & 1.3 \\
Total & 78 & $100 \%$ \\
& & \\
\hline & & \\
& &
\end{tabular}




\begin{tabular}{lll}
\hline Jumlah anak responden & 17 & 21.8 \\
1 & 60 & 76.9 \\
2 & 1 & 1.3 \\
3 & 78 & $100 \%$ \\
Total & & \\
Jumlah keluarga responden & 32 & 41.0 \\
3 & 25 & 32.1 \\
4 & 17 & 21.8 \\
5 & 4 & 5.1 \\
6 & 78 & $100 \%$ \\
Total & 76 & \\
\hline Informasi tentang stunting & 2 & 97.4 \\
Pernah & 78 & 2.6 \\
Tidak pernah & & $100 \%$ \\
Total & 39 & \\
\hline Sumber informasi stunting & 8 & 50.0 \\
Petugas kesehatan & 11 & 10.3 \\
Teman / saudara & 2 & 14.1 \\
Media elektronik & 18 & 2.6 \\
Majalah/koran & 78 & 23.1 \\
Media social & & $100 \%$ \\
Total & & \\
\hline
\end{tabular}

Tabel 2 Distribusi Frekuensi Kategori Pengetahuan Responden Tentang Stunting

\begin{tabular}{lll}
\hline Kategori Pengetahuan & Frekuensi (f) & Persentase (\%) \\
Responden & & \\
\hline Pengetahuan Responden & & \\
Tentang Stunting & 65 & 83.3 \\
Tahu & 13 & 16.7 \\
Tidak Tahu & 78 & $100 \%$ \\
Total & & \\
\hline Pengertian stunting & 18 & 23.1 \\
Tahu & 60 & 76.9 \\
Tidak Tahu & 78 & $100 \%$ \\
Total & & \\
\hline Tanda Gejala Stunting & 37 & 47.4 \\
Tahu & 41 & 52.6 \\
Tidak Tahu & 78 & $100 \%$ \\
Total & \\
\hline Penyebab Stunting & 24 & 30.8 \\
Tahu & 54 & 69.2 \\
Tidak Tahu & 78 & $100 \%$ \\
Total & \\
\hline Pencegahan stunting & 14 & 17.9 \\
Tahu & 64 & 82.1 \\
Tidak Tahu & 78 & $100 \%$ \\
Total & 11 & 14.1 \\
\hline Penanganan stunting & 67 & 85.9 \\
Tahu & 78 & $100 \%$ \\
Tidak Tahu &
\end{tabular}


Dari tabel 1 dapat digambarkan bahwa sebagian besar responden pada kelompok umur 20-30 tahun yaitu 59 orang (75.6\%).Berdasarkan tingkat pendidikan dapat digambarkan bahwa sebagian besar responden dengan tingkat pendidikan SMA yaitu 47 orang $(60,3 \%)$. Berdasarkan pekerjaan suami responden dapat digambarkan bahwa sebagian besar pekerjaan suami responden swasta yaitu 48 orang $(61,5 \%)$. Berdasarkan pekerjaan responden dapat digambarkan bahwa sebagian besar pekerjaan responden swasta yaitu sebanya 36 orang (46,2\%). Berdasarkan penghasilan keluarga responden dapat digambarkan bahwa sebagian besar pendapatan keluarga responden 5.000.000 8.000 .000 yaitu 60 orang $(76,9 \%)$. Berdasarkan jumlah anak responden dapat digambarkan bahwa sebagian besar jumlah anak responden 2 anak yaitu 60 orang $(76,9 \%)$. Berdasarkan jumlah anggota keluarga dapat digambarkan bahwa sebagian besar jumlah keluarga responden 3 anggota keluarga yaitu 32 orang $(41,3 \%)$. Berdasarkan informasi tentang stunting dapat digambarkan bahwa sebagian besar pernah mendengar informasi tentang stunting 76 orang $(97,4 \%)$. Berdasarkan sumber informasi stunting digambarkan bahwa sebagian besar responden mendapat informasi stunting dari petugas kesehatan 39 orang $(50,0 \%)$. Berikut ini disajikan data mengenai kelompok pengetahuan ibu tentang stunting.

Pengetahuan ibu tentang stunting di Desa Lebih Kabupaten Gianyar dengan jumlah responden 78 orang hasil penelitian dapat diukur sebagai berikut.

Dilihat dari karakteristik umur sebagian besar responden dengan kelompok umur 2030 tahun yaitu 59 orang $(75,6 \%)$. Sesuai dengan teori Nursalam (2016) mengatakan semakin bertambahnya umur mempengaruhi daya ingat dan kreatifitas.

Dari karakteristik pendidikan dapat dilihat sebagian besar responden berpendidikan SMA yaitu 47 orang $(60,3 \%)$. Hasil penelitian tersebut sesuai dengan teori yang dikemukakan oleh Depkes (2016), bahwa pengetahuan seseorang dipengaruhi oleh tingkat pendidikan. Pendidikan yang lebih tinggi akan memudahkan seseorang untuk menyerap informasi dan mengimplementasikannya dalam perilaku dan gaya hidup sehari-hari.

Dilihat dari karakteristik responden berdasarkan pekerjaan suami responden sebagian besar bekerja swasta yaitu 48 orang $(61,5 \%)$ Dilihat dari karakteristik responden berdasarkan pekerjaan responden sebagian besar bekerja swasta sebanyak 37 orang $(47,5 \%)$. Hasil penelitian tersebut sesuai dengan teori Pariani (2015) mengatakan pekerjaan suami ataupun istri dapat mempengaruhi pendapatan dan kelangsungan hidup yang lebih baik. Dilihat dari pekerjaan, semakin baik pekerjaan maka ekonomi akan semakin baik pula. Ekonomi akan mempengaruhi fasilitas hidup seseorang. Jika ekonomi atau penghasilan mencukupi kebutuhan keluarga maka hidup seseorang akan terjamin, kebutuhan keluarga tercukupi dan angka kejadian stunting dapat diturunkan.

Dari karakteristik responden berdasarkan pendapatan responden dapat dilihat sebagian besar responden berpendapatan Rp.5.000.000-Rp.8.000.000 yaitu 60 orang (76,9\%). Menurut teori Manuaba (2015) mengatakan semakin tinggi penghasilan keluarga maka kualitas hidup dan kebutuhan keluarga semakin baik dan dapat terpenuhi. Jika kebutuhan keluarga sudah terpenuhi maka kualitas hidup akan lebih baik dan angka kejadian stunting dapat diturunkan.

Jika dilihat dari karakteristik responden berdasarkan jumlah anak sebagian besar responden memiliki 2 anak yaitu 60 orang $(76,9 \%)$ dan sebagian kecil reponden memiliki 3 anak yaitu 1 orang $(1,3 \%)$. Menurut teori dari Tari (2016) mengatakan bahwa semakin banyak mempunyai anak maka semakin banyak pula kebutuhan yang harus di penuhi dan biaya yang diperlukan semakin tinggi untuk menjamin masa depan anak. Semakin sedikit mempunyai anak maka kebutuhan dan biaya yang di perlukan lebih sedikit sehingga dapat menjangkau masa depan anak. 
Berdasarkan jumlah keluarga sebagian besar responden memiliki jumlah keluarga 3 anggota keluarga yaitu 33 orang $(42,3 \%)$. Serta sebagian kecil jumlah anggota keluarga responden 5 anggota keluarga yaitu 2 orang $(2,6 \%)$. Menurut teori dari Handayani (2017) mengatakan bahwa semakin banyak jumlah keluarga yang di tanggung maka semakin banyak pula pendapatan yang harus dimiliki agar kualitas hidup dari semua anggota keluarga dapat terpenuhi.

Dilihat dari responden yang pernah mendapat informasi tentang stunting yaitu 76 orang $(97,4 \%)$ dan sebagian kecil tidak pernah mendapat informasi tentang stunting sebanyak 2 orang $(2,6 \%)$.

Dan dilihat dari sumber informasi tentang stunting sebagian besar responden mendapat informasi dari tenaga kesehatan yaitu 39 orang $(50,0 \%)$. Sedangkan untuk faktor eksternal yang mempengaruhi pengetahuan yaitu berupa informasi yang ibu balita peroleh mengenai stunting dari media sangat terbatas, hal ini disebabkan karena pengetahuan yang mereka miliki hanya sebatas tahu tentang stunting tapi tidak mengerti apa yang harus dilakukan. Sejalan dengan teori yang menyatakan bahwa pengetahuan seseorang dapat dipengaruhi oleh dua faktor yaitu faktor Internal seperti umur, tingkat pendidikan, pengalaman dan pekerjaan. Sedangkan faktor Eksternal seperti informasi, lingkungan dan sosial budaya (Nursalam dan Siti Pariani, 2019).Hal ini sesuai dengan teori Notoatmodjo (2015) yang mengatakan bahwa pengetahuan dan pengenalan pada masyarakat dari pihak terkait merupakan hal yang sangat penting sehingga mendasari terbentuknya tindakan.Pendidikan melalui penyuluhan adalah upaya untuk memberikan pengetahuan sehingga terjadi perilaku yang positif yang mengikat.Selain itu akses terhadap informasi baik media masa, kampanye, penyuluhan dan sebagainya. Seseorang mempunyai sumber informasi lebih banyak akan mempunyai pengetahuan lebih luas.

Dilihat dari hasil penelitian ini sebagian besar responden tahu tentang stunting yaitu
65 orang $(83,3 \%)$ dan sebagian kecil tidak tahu tentang stunting yaitu 13 orang $(16,7 \%)$.

Penelitian ini sebagian besar responden memiliki pengetahuan baik mengenai pengertian tentang stunting yaitu sebanyak 60 orang $(76,9 \%)$ dan sebagian kecil memiliki pengertian kurang yaitu sebanyak 18 orang $(23,1 \%)$. Pengetahuan yang ibu balita hanya sebatas tahu tapi tidak disertai dengan pemahaman yang baik mengenai tanda-tanda dan pencegahan balita mengalami stunting, sehingga kesadaran ibu untuk melakukan pencegahan secara dini yang diikuti dengan melakukan pola asuh dan pemenuhan nutrisi yang baik anaknya menjadi kurang.

Dilihat dari penelitian ini sebagian besar responden memiliki pengetahuan baik tentang tanda gejala stunting yaitu sebanyak 41 orang $(52,6 \%)$ dan sebagian kecil memiliki pengetahuan kurang tentang tanda gejala stunting. Pengetahuan seseorang dipengaruhi oleh pendidikan, usia, dan lingkungan. Penelitian ini sejalan dengan penelitian Tari (2016) yang mengatakan bahwa empat faktor tersebut sangat mempengaruhi pengetahuan ibu.

Hasil dari penelitian ini sebagian besar responden memiliki pengetahuan yang baik terhadap penyebab stunting yaitu sebanyak 54 orang $(69,2 \%)$. Serta sebagian kecil responden memiliki pengetahuan kurang tentang penyebab stunting yaitu sebanyak 24 orang (30,8\%). Menurut Pariani (2015), apabila ibu paham tentang penyebab stuntingmaka ibu dapat memilih cara untuk mengatasi penyebab stunting.

Dilihat dari penelitian ini bahwa sebagian besar responden memiliki pengetahuan yang baik terhadap pencegahan stunting yaitu sebanyak 64 orang $(82,1 \%)$. Serta sebagian kecil responden memiliki pengetahuan kurang tentang pencegahan stunting yaitu sebanyak 14 orang (17,9\%). Menurut Pariani (2015), apabila ibu paham tentang pencegahan stuntingmaka ibu dapat memilih cara untuk mencegah stunting sejak dini.

Dan yang terahir dilihat dari penelitian ini bahwa sebagian besar responden memiliki pengetahuan yang baik terhadap 
penanganan stunting yaitu sebanyak 67 orang $(85,9 \%)$. Serta sebagian kecil responden memiliki pengetahuan kurang tentang pengertian stunting yaitu sebanyak 11 orang (14,1\%). Menurut Pariani (2015), apabila ibu paham tentang penanganan stuntingmaka ibu dapat memilih cara untuk menangani stunting.

\section{Simpulan}

Gambaran Pengetahuan Ibu tentang Stunting di Desa Lebih Kabupaten Gianyar sebagian besar dalam kategori tahu yaitu sebanyak 65 orang $(83,3 \%)$.

\section{Referensi}

Depkes. 2011. Resiko Pendidikan Ibu Terhadap Kejadian Stunting Pada Anak 6-23 Bulan (Material Education As Risk Factor Stunting Of Child 6-23 Months-Old). Panel Gizi Makan.

Depkes. 2015. Riset Kesehatan Dasar. Jakarta : Badan Penelitian dan Pengembangan Kesehatan Kemenkes RI.

Depkes. 2015. Faktor Yang Berhubungan Dengan Kejadian Stunting Pada Balita.Media Gizi Indonesia

Effendy. $2004 . \quad$ Kepmenkes No.1995/SK/Menkes/XII/2010 Tentang metode Penelitian. Jakarta: metodoloengiPenelitian.

Handayani. 2017. Ilmu Gizi menjadi Semakin Mudah. Jakarta.

Manuaba. 2015. Hubungan Asupan Gizi dan Tinggin Badan Ibu Dengan Status Gizi Anak Balita. Jurnal Gizi dan Pangan.

MCN. 2009. Pendidikan \& Konsultasi Gizi. Jakarta: MCN.

Notoatmodjo. 2013. Prevalensi, Faktor Risiko, dan Dampak Stunting pada Anak Usia Sekolah. JITIPARI.

Notoatmodjo. 2015. Hubungan Underlying Factors Dengan Kejadian Stunting Pada Anak Usia 1 - 2 Tahun. Diakses

Nursalam . 2017. MetodePenelitianIlmu Keperawatan, edisi 4. Jakarta : selembamedika

Nursalam. 2016. Stunting dan Masa Depan Indonesia. Jakarta :Diakses
Pariani. 2012. Faktor Risiko Kejadian

Stunting pada Balita Usia24-36 bulan

di kecamatan Semarang Timur

Sariani. 2017. Effect of Micronutrient Supplementation onnDiarrhoeal Disease among Stunted Childreen in Rural South Africa.European Journal Clinical.

Sasmito. 2007. Riset Kesehatan Dasar Jakarta : Badan Penelitian danPengembangan Kesehatan Kemenkes RI

Siswoyo dkk. 2007. Kapita Selekta Kuesioner: Pengetahuan dan Sikap orang tua tentang stunting. Jakarta: Salemba Medika.

Soetjinungsih. 2000. Hubungan Pendapatan Keluarga, Pengetahuan Ibu Tentang Gizi, Tinggi Badan Orang Tua, dan Tingkat Pendidikan Ayah Dengan Kejadian Stunting Pada Anak Umur 12-59 Bulan (Skripsi). Surakarta: Universitas Muhammadiah Surakarta.

Tari. 2016. Panduan Pintar Merawat Bayi dan Balita.

Umeta. 2013. Stunting atau Pendek : Awal Perubahan Patologis atau Adaptasi Karena Perubahan Sosial Ekonomi Yang Berkepanjangan. Media Litbang Kesehatan.

Unicef. 2017. 100 Kabupaten/Kota Prioritas untuk Intervensi Anak Kerdil (Stunting).Jakarta Pusat.

Wibowo Adi. 2008. Hubugan Tingkat Pengetahuan Ibu Tentang Gizi Dengan Status Gizi Anak Balita Di Desa Ngemplak Kecamatan Karangpandan Kabupaten Karanganyar (Skripsi). Surakarta: Universitas Sebelas Maret 


\title{
GAMBARAN PENGETAHUAN REMAJA TENTANG PROGRAM GENRE DI SMP NEGERI 2 PENEBEL
}

\author{
Kadek Sri Ariyanti ${ }^{1,2}$, Ni Made Indra Peratiwi ${ }^{1,2}$, Shonia Margareth ${ }^{1,2}$ \\ ${ }^{1}$ Program Studi Diploma III Kebidanan, ${ }^{2}$ STIKES Advaita Medika Tabanan \\ Korespodensi penulis: ariyanthi.midwife@gmail.com
}

\begin{abstract}
Abstrak
Latar belakang: Program GenRe adalah suatu program untuk memfasilitasi terwujudnya tegar remaja, yaitu remaja yang berperilaku sehat, terhindar dari risiko Triad KRR, menunda usia pernikahan, mempunyai perencanaan kehidupan berkeluarga untuk mewujudkan keluarga kecil bahagia sejahtera. Pentingnya dilakukan penelitian tentang program GenRe agar dapat membantu pemerintah dalam menjalankan program kerja untuk menurunkan angka kejadian pernikahan dini, narkoba dan sek bebas.

Tujuan: Mengetahui gambaran pengetahuan remaja tentang program GenRe di SMP Negeri 2 Penebel.

Metode: Jenis penelitian adalah deskriptif dengan rancangan cross-sectional. Penelitian ini dilakukan di SMP Negeri 2 Penebel, pada bulan agustus 2020 dengan Jumlah sample sebanyak 75 siswa yang di ambil secara random. Instrumen yang digunakan adalah kuesioner yang diberikan secara online dengan item pertanyaan 15 soal dan analisis data menggunakan analisis univariat.

Hasil: gambaran pengetahuan remaja tentang program GenRe di SMP Negeri 2 Penebel sebagian besar dalam katagori baik yaitu 62 responden sebanyak $(82,7 \%)$.

Simpulan : Gambaran pengetahuan remaja tentang program GenRe sebagian besar dalam kategori baik.
\end{abstract}

Kata kunci: Pengetahuan, Program GenRe, Remaja

\section{Pendahuluan}

Masa remaja merupakan masa peralihan dari masa kanak-kanak ke masa dewasa. Menurut WHO (World Health Organization) batasan usia remaja adalah 10 tahun hingga 19 tahun. Batasan usia remaja yang digunakan oleh BKKBN adalah 10-24 tahun dan belum menikah. Sedangkan menurut Peraturan Menteri Kesehatan No 25 tahun 2014, batasan usia remaja adalah 10 tahun hingga 18 tahun. Jumlah Penduduk usia remaja (10-24 tahun) sangat besar yakni mencapai $27,6 \%$ dari seluruh penduduk yang ada di Indonesia (BPS, 2013).

Jumlah remaja yang sangat besar, maka perlu dilaksanakan upaya dalam rangka mempersiapkan remaja menjadi manusia yang sehat secara jasmani, rohani, mental sosial dan spiritual (BKKBN, 2014). Hal yang perlu diwaspadai terkait dengan meningkatnya jumlah remaja adalah muculnya berbagai permasalahan yang terkait dengan remaja. Permasalahan yang paling banyak terjadi pada remaja adalah tingginya persentase pernikahan usia dini yakni sebesar $44,70 \%$. Pengetahuan remaja tentang KRR (kesehatan reproduksi remaja) masih rendah, yakni sebesar $48,4 \%$ pada survei RPJMN (rencana pembangunan jangka menegah nasional) 2014 dan sedikit meningkat pada tahun 2015 menjadi 49\%. Tahun 2016 turun drastis menjadi 32,2\% (BKKBN, 2017).

Menurut Kemenkes RI tahun 2015, Indonesia menempati peringkat 37 di dunia dalam hal pernikahan usia muda serta tertinggi kedua di ASEAN setelah kamboja. Hasil Riset Kesehatan Dasar (Riskesdas) 
tahun 2013 menunjukkan bahwa di Indonesia data pernikahan dini sudah cukup tinggi yaitu $4,8 \%$ pada usia $10-14$ tahun dan $41,9 \%$ pada usia 15-19 tahun. Pernikahan usia dini sering diawali dengan terjadinya kehamilan.

Berdasarkan Data Age Spesific Fertility Rate (ASFR) di Bali ditemukan bahwa kehamilan remaja pada usia dini cukup tinggi. Remaja yang hamil usia $<20$ tahun ditemukan sebanyak 653 jiwa, Daerah Kabupaten Tabanan berada pada peringkat empat di Provinsi Bali dalam hal remaja yang hamil usia $<20$ tahun, sebanyak 71 jiwa (Dinas Kesehatan Provinsi Bali, 2017). Data perkawinan di Kabupaten Tabanan pada usia $<21$ tahun terdapat 1854 jiwa. Jumlah lakilaki yang menikah usia $<21$ tahun 447 jiwa dan perempuan 1407 jiwa. Data pernikahan usia $<21$ tahun lebih banyak ditemukan pada perempuan, hal tersebut di karenakan perempuan menikah dengan pasangannya yang berusia $>21$ tahun (Dinas Pendudukdan Catatan Sipil, 2017). Hasil dari studi pendahuluan bahwa data kehamilan yang cukup tinggi pada remaja yang berusia $<20$ tahun tentunya akan beresiko tinggi pada kesehatan ibu dan bayi.

Program GenRe diharapkan dapat memberikan pengetahuan dan pemahaman mengenai berperilaku sehat, menunda usia pernikahan, mempunyai perencanaan kehidupan berkeluarga untuk mewujudkan keluarga kecil sejahtera. Hal ini diharapkan dapat menekan angka kematian ibu dan anak terutama bagi kaum remaja sekolah yang melakukan pernikahan dini (BKKBN, 2012).

Pengetahuan remaja tentang GenRe sangat penting mengingat program generasi berencana untuk meningkatkan kesehatan remaja. Saat ini usia perkawinan semakin muda (pernikahan dini), remaja usia
SMP/SMA sudah menjadi seorang ayah atau ibu. Cara fisik dan psikologis, mereka belum matang sehingga rentan mengalami masalah dalam rumah tangga baik kesehatan maupun masalah sosial ekonomi (Sarwono, 2012). Oleh karena itu, penelitian melakukan penelitian dengan judul "Gambaran Pengetahuan Remaja Tentang Program GenRe Di SMP Negeri 2 Penebel Tahun 2020" meliput pengertian, tujuan dan strategi program GenRe.

\section{Metode Penelitian}

Penelitian ini menggunakan metode deskriptif kuantitatif. Pendekatan yang digunakan adalah pendekatan crosssectional, karena tujuan penelitian utama dari penelitian ini untuk gambaran tentang penelitian suatu keadaan secara obyektif yang dilakukan hanya satu kali terhadap sekumpulan obyek yang biasanya cukup dalam jangka waktu tertentu (Notoatmodjo,2002).

Lokasi penelitian ini dilakukan di SMP Negeri 2 Penebel. Waktu pengambilan dilaksanakan pada bulan Agustus 2020. Sample penelitian ini adalah siswa SMP Negeri 2 Penebel yang berjumlah 75 siswa. Teknik sampling yang digunakan dalam penelitian ini adalah simple random sampling yaitu suatu teknik penetapan sampel yang dilakukan secara acak tanpa memperhatikan strata yang ada dalam populasi. Sampel tersebut dapat mewakili karakteristik populasi yang telah dikenal sebelumnya (Nursalam, 2017).Dalam penelitian ini analisis univariat yang dilakukan adalah mendistribusikan karakteristik responden yaitu umur, pendidikan dan pekerjaan serta mendistribusikan gambaran pengetahuan.

\section{Hasil dan Pembahasan}

Tabel 1. Karakteristik Responden

\begin{tabular}{llll}
\hline No & Karakteristik responden & Frekuensi (f) & Presentase (\%) \\
\hline & Umur & & \\
2 & $11-12$ & 7 & 9,3 \\
3 & $13-14$ & 4 & 5,3 \\
Total & $15-16$ & 64 & 85,3 \\
\hline
\end{tabular}




\begin{tabular}{llll}
\hline & Kelas & & \\
1 & VII & 26 & 34,7 \\
2 & VIII & 20 & 26,7 \\
3 & IX & 29 & 38,7 \\
Total & & 75 & 100,0 \\
\hline & Informasi GenRe & & \\
1 & Pernah & 45 & 60,0 \\
2 & Tidak Pernah & 30 & 40,0 \\
Total & & 75 & 100,0 \\
\hline & Sember informasi GenRe & & \\
1 & Petugas kesehatan & 35 & 46,7 \\
2 & Teman/saudara & 11 & 14,7 \\
3 & Media elektronik & 12 & 16,0 \\
4 & Majalah/koran & 8 & 10,7 \\
5 & Guru & 9 & 12,0 \\
Total & & 75 & 100,0 \\
\hline
\end{tabular}

Tabel 2 Distribusi frekuensi responden berdasarkan pengetahuan siswa remaja SMP Negeri 2 Penebel

\begin{tabular}{|c|c|c|c|}
\hline No & Pengetahuan GenRe & Frekuensi (f) & Presentase (\%) \\
\hline $\begin{array}{l}1 \\
2 \\
\text { Total }\end{array}$ & $\begin{array}{l}\text { Program GenRe } \\
\text { Tahu } \\
\text { Tidak tahu }\end{array}$ & $\begin{array}{l}62 \\
13 \\
75\end{array}$ & $\begin{array}{c}82,7 \\
17.3 \\
100,0\end{array}$ \\
\hline $\begin{array}{l}1 \\
2 \\
\text { Total }\end{array}$ & $\begin{array}{l}\text { Pengertian } \\
\text { Tahu } \\
\text { Tidak tahu }\end{array}$ & $\begin{array}{l}60 \\
15 \\
75\end{array}$ & $\begin{array}{c}80,0 \\
20,0 \\
100,0 \\
\end{array}$ \\
\hline $\begin{array}{l}1 \\
2 \\
\text { Total }\end{array}$ & $\begin{array}{l}\text { Tujuan } \\
\text { Tahu } \\
\text { Tidak tahu }\end{array}$ & $\begin{array}{l}50 \\
25 \\
75 \\
\end{array}$ & $\begin{array}{c}66,7 \\
33,3 \\
100,0 \\
\end{array}$ \\
\hline $\begin{array}{l}1 \\
2 \\
\text { Total }\end{array}$ & $\begin{array}{l}\text { Strategi } \\
\text { Tahu } \\
\text { Tidak tahu }\end{array}$ & $\begin{array}{l}51 \\
24 \\
75 \\
\end{array}$ & $\begin{array}{c}68,0 \\
32,0 \\
100,0 \\
\end{array}$ \\
\hline
\end{tabular}

Dari Tabel 1 dapat dilihat bahwa dari 75 responden, sebagian besar responden berusia 15-16 tahun yaitu sebanyak 64 responden $(85,3 \%)$, sebagian besar responden dari kelas IX yaitu sebanyak 29 responden $(38,7 \%)$, sebagian besar responden pernah mendengar tentang program GenRe dan sebagian besar responden bersumber dari tenaga kesehatan.

Berdasarkan tabel 4.2 bahwa dari 75 responden pengetahuan tentang pengertian program GenRe pada remaja di SMP Negeri 2 Penebel yaitu sebanyak 60 responden $(80,0 \%)$, pengetahuan tentang tujuan program GenRe pada remaja di SMP Negeri 2 Penebel yaitu sebanyak 50 responden $(66,7 \%)$ dan pengetahuan tentang strategi program GenRe pada remaja di SMP Negeri 2 Penebel sebanyak 51 responden $(68,0 \%)$.

Sebagian besar responden dengan kelompok umur 15-16 tahun yaitu 64 orang $(85,3 \%)$ memiliki pengetahuan yang lebih, ini sesuai dengan teori menurut Mubarak (2011) Umur mempengaruhi terhadap daya tangkap dan pola pikir seseorang. Dengan bertambahnya umur individu, daya tangkap dan pola pikir seseorang akan lebih berkembang, sehingga pengetahuan yang diperolehnya semakin membaik.

Menurut Notoadmojo (2012) umur seseorang semakin tua maka proses perkembangan mentalnya bertambah baik. Umur sangat berpengaruh pada pengetahuan, umur yang cukup memiliki pola pikir dan 
pengalaman yang matang sehingga pengetahuan yang diperolehnya semakin baik.

Paling banyak responden dari kelas IX yaitu 29 orang $(38,7 \%)$, sesuai dengan teori menurut Mubarak (2011) bahwa pendidikan merupakan suatu usaha untuk mengembangkan kepribadian dan kemampuan seseorang agar dapat memahami suatu hal. Pendidikan mempengaruhi proses belajar, semakin tinggi pendidikan seseorang, semakin mudah orang tersebut menerima informasi. Pengetahuan sangat erat kaitannya dengan pendidikan dimana diharapkan seseorang dengan pendidikan tinggi, maka orang tersebut akan semakin luas pengetahuannya.

Menurut Notoadmojo (2012) suatu usaha untuk mengembangkan kepribadian dan kemampuan di dalam dan di luar sekolah dan berlangsung seumur hidup. Pendidikan mempengaruhi proses belajar, makin tinggi pendidikan seeorang makin mudah orang tersebut untuk menerima informasi.

\section{Simpulan}

Simpulan penelitian ini adalah gambaran pengetahuan remaja di SMP Negeri 2 Penebel sebagian besar dalam katagori baik yaitu sebanyak 62 responden $(82,7 \%)$.

\section{Referensi}

Arikunto, S. 2006. Prosedur Penelitian Suatu Pendekatan Proses Edisi Revisi. Jakarta : Rineka Cipta.

Aziza, SP, MP TN, Itcianday I. Peranan "INCAR" (Informasi Cerdas Ala Remaja)

Dalam Program GenRe (Generasi Berencana) di Kabupaten Nunukan. J Borneo Adm. 2018.

BKKBN. 2017a. Survei Iendikator Kinerja Program KKBPK RPJMN Keluarga. Jakarta: Badan Kependudukan dan Berencana Nasional.

BKKBN. 2017b. Survei Kependudukan, Keluarga Berencana, Kesehatan Reproduksi Remaja dan
Pembangunan Keluarga di Kalangan Remaja Indonesia. Jakarta: Badan Kependudukan dan Berencana Nasional.

BKKBN Provinsi Jawa Timur. 2014. GenRe Generasi Berencana. Surabaya: Perwakilan Badan Kependudukan dan Keluarga Berencana Nasional Provinsi Jawa Timur.

Desiyanti, I.W. 2015. Faktor-Faktor yang Berhubungan Terhadap Pernikahan Dini Pada Pasangan Usia Subur di Kecamatan Mapanget Kota Manado. Jikmu, [e-journal] 5 (2), pp. 270-280.

Hayati, E., Amir, P., Asfriyati. 2016. Pengaruh Komunikasi Persuasif Bidan Terhadap Pengetahuan dan Sikap Ibu Tentang Pemberian MPASI Di Desa Pasar Maga Kecamatan Lembah Sorik Merapi Kabupaten Mandailing Natal Tahun 2016.

Indah,Firdayanti N. Icite \{Annisa2016,IndahFirdayanti201

9,Unknown\}. J Widwifery. 2019.

Jurnal Penelitian Pendidikan Sosial Humaniora, [e-journal] 1 (2): pp. 72 79. Lago, M.N. 2017. Eksploitasi Tubuh Perempuan Di Media Televisi (Analisis Semiotika Makna Pesan Iklan Cat Avian Syntetic Versi Awas Cat Basah). Jurnal Online Kinesik, [e-journal] 30 (2): pp. 30-36.

Rachma AA. Gambaran Tingkat Pengetahuan Remaja Tentang Kebersihan

Organ Genitalia Eksterna Di Sman 90 Jakarta.; 2016.

Tanjung RDS. Analisis Pengetahuan Remaja Tentang Program Generasi

Berencana Di Smu Negeri 1 Marbau Tahun 2018.

Notoatmodjo, S. 2010. Metodologi Penelitian Kesehatan. Jakarta : Rineka Cipta.

Notoatmodjo S. 2007. Promosi kesehatan dan ilmu perilaku. Rineka cipta: Jakarta.

Notoatmodjo, S. 2014. Ilmu Perilaku Kesehatan. Jakarta: Rineka Cipta 